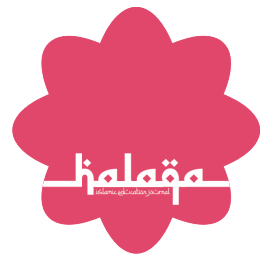

OPEN ACCESS ISSN 2503-5045 (online) ISSN 1412-9302 (print)

Edited by: Musfiqon

Reviewed by: Eni Fariyatul Fahyuni

${ }^{*}$ Correspondence: Imam Faisal Hamzah

imamfaisalh@ump.ac.id

Received: 15 Desember 2020

Accepted: 25 Desember 2020

Published: 25 Januari 2021

Citation:

Hamzah IF, Akbar ZY and Grafiyana

GA (2021) Social Identity of

Non-Moslem Students In

Muhammadiyah Universities.

HALAQA:ISLAMICEDUCATION

JOURNAL. 5:1.

doi: 10.21070/halaqa.v5i1.1109

\section{Social Identity of Non-Moslem Students In Muhammadiyah Universities}

\section{Identitas Sosial Mahasiswa Non-Muslim Di Perguruan Tinggi Muhammadiyah}

\author{
Imam Faisal Hamzah*, Zaldhi Yusuf Akbar, Gisella Arnis Grafiyana \\ Faculty of Psychology, Universitas Muhammadiyah Purwokerto, Indonesia
}

Education in Indonesia, especially higher education institutions, has a role to build interaction between religious adherents. How is this experience of tolerance in religiously based higher education institutions where the majority of students and staff are religious according to the institution. One of the largest religious-based higher education networks in Indonesia is the Muhammadiyah Universities or Perguruan Tinggi Muhammadiyah (PTM) network. Muhammadiyah as one of the largest Islamic organizations in Indonesia which has a network of higher education spread across various parts of Indonesia where students studying have diverse religious backgrounds. This study aimed to examine the dynamics of social identity in the experience of non-Moslem students at Muhammadiyah College. This research uses qualitative research methods using Interpretative Phenomenological Analysis (IPA). Six participants, Christian, Catholic, Hindu, and Buddhist from four Muhammadiyah College in the province of Central Java - Indonesia, were interviewed and analyzed to obtain core themes. The results of this study produced five superordinate themes, namely the influence of the environment, personal characteristics, perceptions of the religion adopted, experience as a Muhammadiyah College Student, and perceptions of Islam and Muhammadiyah. The conclusion of this study shows the psychological dynamics of non-Muslim students shape the perception of Islam itself as a religion, also Muhammadiyah as an Islamic organization.

Keywords: Islamic College, Muhammadiyah Universities, Non-Moslem Students, Social Identity, Tolerance 


\section{INTRODUCTION}

Muhammadiyah's education network has become a hallmark of Indonesian life. Muhammadiyah's role, starting from the earliest to the highest education level, has been widely spread throughout Indonesia. Muhammadiyah (2018) explained information on the number of Muhammadiyah Universities (PTM). There were around 174 Muhammadiyah Universities and 'Aisyiyah (PTMA) in 2018 distributed in 166 universities of 16 academies, three polytechnics, five institutes, 95 higher schools, and 47 universities. While 'Aisyiyah Universities (PTA) consisted of 8 colleges divided into two academies, one polytechnic, four higher schools, and one university. As one of the most prominent Islamic-based community organizations in Indonesia, Muhammadiyah's role is closely linked to education. Since it was established by one of the national heroes KH Ahmad Dahlan on November 18th, 1912, Muhammadiyah's contribution to the nation's education was already very identical. Likewise, the primary function of Muhammadiyah Universities itself is under the Guideline of Muhammadiyah Central Executive Number 02/PED/I.0/B/2012 relating to Muhammadiyah Higher Education which states:

"PTM roles as a center of excellence within the region (uswah hasanah, center of excellence) in the fields of education, research, and community service as well as the driving force of the Muhammadiyah missionary and tajdid movement which crosses the age for the realization of a pure Islamic community."

Here, PTM has a mission to "realize the true Islamic community." However, the role of Muhammadiyah cannot be separated from its identity as an Islamic-based community organization. In reality, the users of Muhmammadiyah education are not only from Muslims and Muhammadiyah followers. Mu'ti and Haq (2009) illustrated how Muhammadiyah Education also offered educational rights for non-Muslims in the archdiocese of Ende, East Nusa Tenggara, especially secondary education. Does PTM also provide the same educational rights? The Guideline of Muhammadiyah Central Executive Number 02/PED/I.0/B/2012 on the Muhammadiyah Higher Education mentions no restrictions on students' background, which should come from Muslims only. It means that non-Muslims are also eligible to study in Muhammadiyah higher educations.

The phenomenon of non-Muslim students studying in Muhammadiyah Higher Education also impacts in university policies. For instance, Kusuma (2016) issued that the nonMuslim students of Universitas Muhammadiyah Yogyakarta, who came from Eastern Indonesia and abroad, were also tolerated not to wear the hijab for female. The Higher Education noticed the presence of non-Muslim students studying at Muhammadiyah Higher Education. Research and Development Board (Diktilitbang) of the Central Executive (PP) of Muhammadiyah along with some Muhammadiyah Universities from eastern Indonesia discussing the material of $\mathrm{Al}$ Islamdan Kemuhammadiyahan (AIK) for Non-Muslim students (Universitas Muhammadiyah Malang, 2017). Recently, there were 26 non-Muslim students recorded based on student data of UMP Academic Administration Bureau (BAA) Universitas Muhammadiyah Purwokerto in 2019. The data were students who are still active and have completed their education at UMP. There were 16 Christian students, 9 Catholic Students, and 2 Hindu students.

There was an interesting response of non-Muslim alumni in filling the Alumni Survey. One of the questions was about the need for Islamic values integration in the curriculum. The alumni's answer was "less necessary." At a glance, there was a response from his attitude towards learning in the UMP which carried Islamic values. This attitude could arise from the way individuals define themselves in a member of social groups or referred to as social identity Haslam (2004) . Tajfel (1982), one who stated about social identity, confirmed that social identity was part of an individual's self-concept, which comes from his attachment to values and emotions based on the individual's knowledge of his membership in a social group.

Individuals will categorize others in a group or out-groups, classify themselves as part of a group or in-groups, and often assess their group more favorably than others Cottam et al. (2010). Therefore, a group member can try to defend his group as part of the groups so that the group remains positively evaluated. The first issue to be discovered in this study is how non-Muslim students interact with different social environments of religious identity. Besides, the students must face the university policies which adopted Islamic values in the education system. Isnaini (2014), at the University of Muhammadiyah Malang, stated that Non-Muslim students responded positively to the Al-Islam and Kemuhammadiyahan courses and to the Islam religion itself. It was supported by Harisman (2018) conducted at the Muhammadiyah University of Purwokerto where non-Muslim students felt better in learning their religious lessons. However, previous studies have not revealed the psychological and social aspects of social identity as non-Muslim students at PTM. Therefore, this study aims to examine the dynamics of social identity in the experience of non-Muslim students at Muhammadiyah Universities.

\section{METHOD}

This study implemented a qualitative method with Interpretative Phenomenological Analysis (IPA) approach. Smith et al. (2013) revealed that IPA was a qualitative psychological research approach which sought to express experiences gained from information concepts from three key areas of science philosophy; phenomenology, hermeneutics, and idiography. The primary method of this study was semi-structured in-depth interviews, where Smith and Osborn (2006) stated that the interview had guidance but it was flexible, so it required several things such as building rapport with participants, questions were sometimes in random, researchers were free to ask questions about interesting areas arise, and interviews could follow the respondents' interests. Smith et al. (2013) proposed 
the process of analyzing IPA data, which included reading and re-reading (repeated interview based on transcript), initial noting, developing emergent themes, searching for connections across emergent themes, moving to the next case, and looking for patterns across cases.

Participants in this study consisted of 6 students spread across several PTM in Central Java. Criteria for participants in this study were registered as active students in one of the Muhammadiyah Universities on 3rd semester, at least in Bachelor education, having another religion than Islam, and willing to be a participant by signing informed consent. General information about participants is presented in Table $\mathbf{1}$

[Table 1 about here.]

\section{RESULTS AND DISCUSSION}

Data collection was conducted between October and December 2019. Participants agreed to conduct the study by signing an informed concent provided by the research team. Face-toface interviews are conducted in Indonesian. Some things that have not been confirmed in a face-to-face interview, then the research team followed up through an online interview via the chat feature on one of the social media. The results of the interview were then transcribed, then the research team handed it back to each participant to make corrections if there were inconsistent statements. Based on data analysis, it discovered five core themes related to the experiences of non-Muslim students at Muhammadiyah Higher Education, namely the effect of environment, the religion judgment, personal characteristics, experience as a PTM Student, and an assessment of Islam and Muhammadiyah. Those superordinate and core themes, the author described in Table 2 .

[Table 2 about here.]

\section{Family Effects}

The environment is more highlighted in the social environment. The dynamics of social influence also affected students' decision making to study at PTM and the participants' attitude while interacting on campus. Participant D claimed that his choice to study at PTM was due to the wishes of his parents. Cost considerations were decisive, according to $\mathrm{D}$, that his parents chose PTM as D's place of study. Besides, the experience of D's sister and uncle to study in the same PTM. D thought that the opinion of D's parents were very "familyable" to the lives of their children, including their children's choices religion and in life.

"Pertama tuh karena udah daftar SBMPTN, trus gagal kalau sama orang tua daripada kuliah jauh tapi ambilnya itu di swasta, mending disini" (D, 14-15) [Because I have participated in SBMPTN (Joint Entrance Selection of State Universities) but failed. Then, instead of studying in private and far university, here is better (D, 14-15)]

Similar to D, participant F also chose to study at PTM because of its affordable costs. Moreover, access to campus was not far from his home. F defined, "There are two kitchens. (F, 61) "It was to illustrate the costs to cover by F and his mother. Participant $F$ said that his mother still helped him pay for college, even though F, who had previously worked, could finance his college expenses. Especially, after his mother remarried to a Muslim, F became a tolerant person by learning from his parents who lived side by side despite religious differences.

Something similar happened to B, where his parents married a different religion, his father was a Christian, and his mother was a Muslim. Nevertheless, B parents always educated about independence and responsibility for his life choices. This attitude brought B to study at PTM without any influence from anyone. Participant B chose to study at PTM because of the relatively affordable cost, especially with B's effort to pay for his own life.

"Karena ibu saya dari dulu mengajarkan saya, terutama islam. "kamu boleh memilih apapun yang kamu mau, asal kamu punya tanggung jawab. Mamah di sini mengatakan bahwa dia itu NU, emang daerah pati itu kebanyakan NU. Nah disini Muhammadiyah. Nah tapi mama nggak ingin membedabedakan kayak disana itu kayak ajarannya jelek, nggak pengin. Semua itu tentang kebaikan dengan cara yang berbeda." (B, 180-184) [Because my mother always taught me, especially Islam. "You can choose whatever you want, as long as you have responsibilities. His mother said that she was Nadhatul Ulama (NU); indeed, Pati regency was mostly NU. However, here is Muhammadiyah, but I do not want to discriminate that Muhammadiyah teaches something bad. It is all about kindness in a different way. (B, 180-184)]

The effects of parents' religious attitudes also appear in participant $\mathrm{L}$, where L's parents reminded $\mathrm{L}$ to remain steadfast in his religious establishment despite being in a Muslimmajority environment. However, L's parents advised to study at PTM, even though L claimed that he had been accepted at several universities outside his city. Participant L admitted that he really depended on his parents, and it was difficult to get far from his parents. Participant L studying at PTM became an option so that he would not be far from his parents. L's parents chose PTM because of the institution's and departments' quality, even compared to public universities in the city. Although L considered tuition fees are relatively expensive, the cost of living is more affordable.

$\mathrm{T}$ also felt the relatively high cost, but with a more affordable cost of living. T chose to study at PTM because of previous family experiences. Besides, the expected department was also available in the PTM.

$\mathrm{W}$ experienced the same in choosing PTM because of the availability of the department he wanted. W, who came from outside Java, received encouragement from parents to study in Java. Besides, W attended PTM was also because there were relatives who studied PTM before. Even so, W's parents also keep 
monitoring $\mathrm{W}$ because he studied in a Muslim majority place.

The author concluded the interdependence between participants and their families that affected individual diversity's college decisions and attitudes. This dependence could be in the form of financial or emotional, such as a sense of security. Besides, the influence of the family in shaping the religion of the participants.

\section{Personal Characteristics}

Besides the effect of the environment, especially the family, the participants also had personal characteristics to judge themselves in the middle of their social groups. It would help them to determine the tendency of participants to choose majors, universities, and interests to learn other religions, including Islam.

$\mathrm{D}$ liked learning new things, such as interest in listening to lectures from other religious leaders. It was based on the need to stabilize himself, so the lectures he listened to adjust to his conditions, including D's decision to wear hijab when she was in the campus environment, although there was no requirement for D to use it.

$\mathrm{F}$ also liked to learn new things, but for F, to be loyal to his religion is a responsibility, as expressed by participant $\mathrm{F}$ below.

"Ya kan.. gimana ya Bu kalau misalkan kita sampai pindah agama itu kan dah nunjukin kalau kita itu bukan orang yang apa ya.. setia Bu ama suatu hal apapun." (F, 545-546) [Yes, mam, if we change to another religion, it means that we are not like... a loyal person, mam, for everything. (F, 545-546)]

"Kalau yang nonisnya ini orang yang mungkin nggak nggenah dan kurang tanggung jawab." (F, 468) [For the nonmuslem, this might be a bad person and lack of responsibility. $(\mathrm{F}, 468)]$

L got along with friends from other religions during high school; it encouraged L to show an interest in learning new things, including studying Islam. Nevertheless, L also remained steadfast in his stance on religion.

"Tapi kalo secara pribadi si emang saya kan suka bergaul gitu ya pa ya, saya juga dulu pas sekolah SMA tuh temen saya macem-macem ada yang kristen, ada yang hindhu, budha, tapi saya emang suka mempelajari sesuatu yang baru. Emang pa, emang saya belajarnya ke agama islamnya, tapi saya mintanya tuh kalo emang saya suruh mempelajari agama islam, itu dari dasarnya loh pa, jangan langsung tinggi. Sama halnya dengan saya enggak paham apa-apa." (L, 431-436) [Personally, I like to hang out that way, yeah, I also used to be friends in high school with Christians, Hindus, Buddhists, but I really liked learning something new. Actually, I did study about Islam, but I asked to learn Islam from the easiest one, not the hardest. Otherwise, I will understand nothing. (L, 431-436)]

Unlike the other three participants, B expected to learn Islam because he wanted to know more about it. It was driven by B's personal characteristics, which is independent, including the independence to think and determine his interests. This encouraged B to study Islam independently and discuss with others which B considered to understand his personality. For example, B decided to study in a new city where B had never lived in the city before.

A person who liked to experience new things was also shown in $\mathrm{W}$, not in religious matters, but something related to a challenge, such as blood. W's fondness for blood then determines one of W's selection of department related to health. Meanwhile, one of the PTMs indeed provided his interested majors.

Personally, T was persistent and respected others, especially in terms of religion. He tried to get the best educational institution for himself. Even though the university was in the Islamic environment, T presented respect to PTM. His persistence was also visible from his story by comparing students from the same area as participants who tended to spend money rather than studying.

It could be drawn that personal characteristics, such as enjoying new things and respecting others, including religion, determine how participants chose and adapted to the Islamic PTM environment. It was driven by the desire to learn new things about new insights and compare their religion with other religions when they become students at Muhammadiyah Universities.

\section{Judgment to the Committed Religion}

Most participants judged their religion positively, except B, who considered their religion as a memory. B's judgement did not eventually make him move to a new religion, but B said that he was still steeped in Islam's teachings. The teachings adopted by his biological mother. B embraced Christianity because his childhood experience was rarely with his parents but more with his grandmother.

D stated that worship was a choice. Participant D believed that there were already many teachings in his religion, but it depended on their beliefs, whether they would implement these teachings. D found peace in worship and wanted to continue this way, moreover, when the congregation was done.

$\mathrm{F}$ viewed that his religion was amorous. With this belief, $\mathrm{F}$ considered that other religions were the same. F did not believe that all religious people were members of a radical group.

"Kenapa ya yang di Nasrani ada gini, di Islam ada gini di Hindu ada gini di Budha ada gitu. Cuma kayak mau tau apa kah semua itu masih sama. Sama itu ya pakai cinta kasih. Kan yang saya tahu beragama itu kan dengan cinta kasih." (F, 98100) [Why is it Christianity teaches this way, Islam teaches this way, and Hinduism and Buddhism. Are they still the same, with love. What I know that believers should be amorous religion. (F, 98-100)]

$\mathrm{L}$ considered that religion teaches about modesty, but $\mathrm{L}$ tended to interpret his modesty inferiorly. L believed that modesty meant silence in ostracized or tortured. L was not happy if his religion was demonized or his religion was demonizing other religions.

$\mathrm{T}$ tended to view religion as respecting others. If someone wanted to be respected, they must respect others first. How- 
ever, he was not from a Muslim area and had no experience interacting with the Muslim community before attending college.

W felt very happy when carrying out his religious worship. $\mathrm{W}$ expressed his joy because the series of worship rituals had its artistic elements.

"Ada tari-tarian juga. Ada kesenian kan banyak kalau setiap ibadah. Jadi kayak nggak sabar, 'ih tar malem pengen pura "' ( W, 146-147). [There are dances too. There are a lot of artistry in every worship. So I can't wait 'tonight, I expect something' (W, 146-147).]

It could be drawn that religion was something positive for participants and others because religion established peace, fun, full of love, balancing an unstable situation. Disbelieve to a religious was considered unfaithful in everything, but $\mathrm{B}$ also saw it as a quest. However, this came back to the personal characteristics of each individual.

\section{Experience as a PTM Student}

As previously stated, participants' tendency to study at PTM was due to family recommendations. However, it could not be separated from other factors such as cost, availability of majors, the proximity of residence, and accreditation. For B, the place to study was to establish connections with alumni, seniors, and friends. Besides, B also learned many new things while studying at PTM, especially in the art department. The policy of wearing the hijab for non-Muslim female students seemed to be an issue. Not all participants were comfortable to wear the hijab because they are not familiar with it, but some lecturers in some PTM required non-Muslim students to wear the hijab during lectures. D then chose to keep using it until outside the class, which required him to wear the hijab. In the early semester, D did not wear the hijab. However, as a form of appreciation to the majority of Muslims at PTM, finally, D also wore the hijab.

T was satisfied with the services provided by PTM, including the freedom given by the PTM not to require nonMuslim students to attend Islamic-based lectures, such as AIK (Muhammadiyah and Islamic Subjects). Initially, T thought that PTM was a national campus that was not based on religion, but apparently, T was surprised because PTM was an Islamicbased institution. $T$ said that she was surprised when he first came to Islamic PTM. For example, when T participated in an orientation where the majority of participants used the hijab. Even so, $\mathrm{T}$ chose not to wear the hijab, but $\mathrm{T}$ learned from the policy about modesty in attire.

" $K$ alau soal pakaian enggak sih, soalnya kan baik juga buat kita ya." (T, 234) [I have no problem with the clothes because it is also good for us. (T, 234)]

Similar to T, another participant, $\mathrm{W}$ also chose not to wear the hijab. Although in some forums, such as the choir stage, $\mathrm{W}$ wore the hijab. $\mathrm{W}$ felt being respected as a minority in PTM. Especially when the rector, in his speech at an orientation event, guaranteed non-Muslim students' convenience to study at PTM. Another reward from the lectures, there was no obligation for non-Muslim students to attend Islamic lectures, but if non-Muslim students want to attend AIK lectures were still permissible. Religious-based lectures were tailored to each student's religion, for example, Hinduism was assigned to its religious leaders.

"Cuma dosennya memang bilang kalau ingin kuliah ikut nggak apa-apa, nggak juga nggak apa-apa, katanya gitu. Ya daripada nunggu jam kosong jadi ikut, nunggu mata kuliah selanjutnya jadi ikut masuk aja." (W, 175-177) [The lecturer stated that we can choose to join the class, instead of waiting for a free class or waiting for the next class to join in. (W, 175177)]

F used lectures with Islamic values to add his insights into the Islamic religion. The advantage, the policy to liberate Islamic lectures could provide new insights for non-Muslim students about Islam. Also, lecturers gave many flexibilities to non-Muslim students when attending AIK lectures, for example, flexibility for not following the Islamic prayer practice.

Some PTMs were required to attend these courses for nonMuslim students. Consequently, as stated by L, he felt that his religion was unrespected. $\mathrm{L}$ said that the teachings of Islam delivered in the lectures he followed were too high, while $\mathrm{L}$ could not understand the basis of Islam properly. L sometimes had discussions about religion too with his Muslim friends.

\section{Judgment of Islam and Muhammadiyah}

There were not many non-Muslim students who understood Islam and especially Muhammadiyah itself. Some equated it like Christians and Catholics or Hindus and Buddhists to analogize between Muhammadiyah and Nahdatul' Ulama. Nevertheless, the participants learned many things from religious teachings and their believers' behavior while studying at Muhammadiyah Universities (PTM). The experience of participants studying in PTM directly or indirectly provided various judgments for Islam as a religion and Muhammadiyah itself as an Islamic organization. PTM could be a bridge or media for non-Muslim students to answer their confusion to that question. The image of Islam in believers of other religions' eyes was invaluable from the interaction between non-Muslim students and the entire academic community at PTM, in which the majority were Muslims.

$\mathrm{L}$ considered that Islam was a good religion. Before studying at PTM, L had received many warnings from his friends related to studying at Islamic-based institutions such as PTM. The presumption of ostracization turned out to be different from the reality experienced by L. PTM environment where L obtained her study was good with non-Muslim female students. For example, non-Muslim female students were not required to wear a hijab. On the other hand, L was also disappointed in her Muslim friends who did not wear a hijab outside the campus.

$\mathrm{W}$ and $\mathrm{T}$ learned something from Muslims. W learned about perseverance; for example, the experience of W saw Mus- 
lims whom he knew were diligent in worship. W claimed an increase in the intensity of worship after hanging out with his Muslim friends while studying at PTM.

"Jadi kayak, sebelum aku kenal mereka kan sembayangnya masih sering boplong-bolong. Terus kalau ibadah kan mikirnya jauh juga. Jadi kayak males gitu. Tapi mereka ada yang sering nganterin kalau mau ibadah. Jadi kayak lebih rajin itunya sih ibadahnya semenjak sama mereka." (W, 257-259) [So I was inconsistent in praying before I knew them. Besides, it is also quite far to do the prayer and makes me lazy. But some of them escort me to do my prayer. So, it feels I am more diligent in doing the worship since with them. (W, 257-259)]

Similar to W, participant $\mathrm{T}$ learned about politeness. For example, $\mathrm{T}$ learned how to dress politely. The polite dressing was not only good for Islam but also for other religions. Furthermore, T said that Muslims were very obedient to their religion, but also able to appreciate religious differences without coercion.

D also felt that even though Muslims were the majority students but they were tolerant towards the minority. D had no unpleasant experience while studying at PTM. D also liked to learn new things, such as religion. D expressed his pleasure when he could learn other religions.

Participant $\mathrm{F}$ admitted that he was confused about studying Islam because some Islamic teachings were difficult to understand. For example, how a murder then enter heaven? The concept of halal and haram also made him confused. It was compared by participant $\mathrm{F}$ with the teachings of his religion which, according to him, as long as someone did not steal, it was considered halal.

B considered that Islam was sacred. Participant B quoted the phrase from Cak Nun "it teaches goodness. However, this is not limited to religious identity but also the believers' behavior." The researcher concluded that Muhammadiyah universities could represent a good image of Islam, and Muhammadiyah illustrated excellent views for non-Muslims. It was delivered in the form of teachings of religion subjects that were then taught by lecturers and Muslims' behavior in it. Borrowing B's expression,

"Jadi saya lebih mengenal orang itu bukan dari dia agamanya apa, dia bedanya dimana, enggak, tapi bagaimana dia berperilaku. (B, 155-156)" [So I get to know the person better not from the religion, or the difference he makes, but how he behaves. (B, 155-156)]

There were three highlighted things based on this study: interaction between students of different religions, educational policies, and leadership. First, non-Muslim students' interaction in Muhammadiyah Higher Education affected the interaction between religious identities on campus. As part of social identity, religious identity could lead to a conflict when there was a competition between groups. According to Setiawan et al. (2020) stated how collective efficacy mediated the correlation between religious dimensions and violence among religions, where Muslim groups tended to have higher collective efficacy than Christian groups. Almost similar to that, Neu- berg et al. (2014) also illustrated the tendency for aggression towards other groups when believers have different values. Dixon et al. (2017) conveyed the correlation between these groups through the contact hypothesis, where Muslim students and most Hindu students in New Delhi were involved in solidarity actions. Muhammadiyah University was a miniature of Muhammadiyah to realize its organizational goals, namely, to purify the Islamic community. The interpretation of the pure Islamic community indeed referred to the people in the time of prophet Muhammad. The Islamic community also guaranteed believers of other religions; in Islam, non-Muslims in such protection were called Ahl-Al-Dzimmah Untung and Sutrisno (2015) .

Higher education institutions in Muhammadiyah as the miniature already had a reputation of being an institution that advanced a progressive understanding of Islam about pluralism, democracy, and human rights Pohl (2009). There are, of course, many different perspectives on Pluralism, Mukti and Haq (2009) visualized pluralism did not mean that all religions were the same and become a new religion, but an affirmation of differences and respect for those differences, as well as accepting and accommodating differences through the constructive way. Zarkasyi (2012) viewed philosophical pluralism as actually containing the understanding of western relativism and nihilism in which there was no single truth or even no truth at all, primarily aimed at religion, but Zarkasyi agreed that there was a plurality of cultures, ethnicities, races, etc. Untung and Sutrisno (2015) argued that the unaccepted pluralism in an Islamic perspective viewed all religions as the same. Zarkasyi also explained that pluralism and tolerance were two different things, so someone might not be a person who behaved pluralism but showed a tolerant attitude. Apart from the differences of opinion related to pluralism, at least both opinions acknowledged tolerance between religious communities. It was an essential background for the realization of solidarity. As a moderate Muslim group (al-wasath) Muhammadiyah (2017), Muhammadiyah could present a tolerant attitude. Wibisono et al. (2019) explained that moderate Muslim groups in Indonesia tended to accommodate other identities besides religious identities, which did not occur in fundamental activist groups.

For Muhammadiyah, this attitude was available in the Muhammadiyah Principles about Life, which encouraged tolerance to realize the real Islamic community (Muhammadiyah Central Executive, 2009) Pusat (2009) . Islam respected religious freedom and believers of other religions, and nonMuslims who lived in the Islamic region were entitled to the same rights and treatment as Muslim citizens Untung and Sutrisno (2015). Besides, religious tolerance in Indonesia, especially in Muhammadiyah Universities, was caused by religious diversity exposure and intellectual modesty Hook et al. (2017). The second was the education model policy adopted by each PTM. Researchers discovered that non-Muslim students studying at Muhammadiyah Universities felt comfortable, safe, and even highly respected. A similar thing was presented by Kurni- 
awan (2018) in his research in schools that included Islamic values in the curriculum. Educational institutions were not only limited to learn about skills, but they also had to provide social goals, for example, how a student interacted with others Akerlof and Kranton (2010). Mukti and Haq (2009) mentioned three education models of school-based education. First, exclusive, when all students received one religious subject. Second, inclusive model, when all students leaned all religions and found things in common and differences from the religions, and finally, pluralist model, when students learned confessional religions according to the law, and nonconfessional according to the school's common religion at the same time. At the level of higher education in PTM, this situation turned out to be different in the policy. However, psychologically the researcher found more positive attitudes towards PTM with a pluralist model of education policy.

Islamic education in the PTM environment became a means of dialogue between religious communities, which fostered tolerance. Matulessy (2018) explained that tolerance was based on the need to dialogue about each other's problems so that it could produce objectivity to accept the presence of others and also empathy, which felt what was felt by others. Sammut and Gillespie (2011) stated that this attitude would establish solidarity because of the negotiation process between identities within. Christie and Dawes (2001) called this as solidarity, that is, tolerance among the groups. This attitude needed to be developed in a pluralistic education. Here, PTMA, as one of religious-based higher education institutions, was demanded to show the image of Islam, which presented a high solidarity attitude and was able to reduce prejudice to discrimination in the name of religion. Burch-Brown and Baker (2016) also conveyed the same thing that religion could reduce prejudice among groups as long as the religion provided appropriate teachings and beliefs and more extensive interaction among groups.

The third is the role of the leader of the Muhammadiyah Universities, here as the policymaker. The role of leaders, in this case, was also significant in building solidarity among groups. Selvanathan, Khoo, and Lickel (2019) research discovered leaders' role in building inclusiveness in community affiliation. Leaders, as policymakers, would create a comfortable environment to interfaith life. Abu-Nimer and Smith (2016) mentioned the importance of social policymakers in supporting the integration of inter-religion and culture in formal education. Hogg et al. (2012) suggested that the key to intergroup leaders' success was the existence of inter-group relational identity. It was established through the leaders' rhetoric in struggling for collaboration between groups as a valued aspect of group identity, giving examples of correlation among groups, forming the boundaries of the leadership coalition, and the rhetoric of the leader to stimulate the formation of a new collaboration of established intergroup relations. In terms of leadership in PTM, researchers could not find similar studies, so it could also be an opportunity for further research. However, Burhani (2018) 's opinion about the role of Muhammadiyah leaders in facilitating differences within Muhammadiyah itself with a focus on social services required cooperation.

This research was considered able to describe the attitudes and positions of non-Muslim students in Muhammadiyah Universities as an Islamic educational institution. Thus, this research could also be a discourse for Islamic-based Higher Education specifically and other religions in general. However, this study could not describe the attitudes and positions of these students as a whole towards Muhammadiyah itself, so a further study was necessary.

\section{CONCLUSION}

This study is answering the research objective in examining the dynamics of social identity in non-Muslim students' experience at Muhammadiyah Universities. This study reveals psychological experiences of non-Muslim students at PTM. NonMuslim students strive to adapt to a predominantly Muslim environment by respecting university policies. On the other hand, non-Muslim students feel an acceptance and tolerance while studying in PTM. Muhammadiyah Higher Education (PTM) can be a good image for Islam and for Muhammadiyah itself. The goodness of the teachings and the behavior of lecturers, staff, and Muslim students reflect non-Muslim students to evaluate Islam and Muhammadiyah positively. This research still needs further process to explore the psychological side of non-Muslim students at PTM and how the policy implications for the religious life of these students. There are at least two policies which become major themes in this study related to the hijab policy and the obligation to attend in Al-Islam and Kemuhammadiyahan subjects. In addition, the leaders' role in PTM needs to be further studied.

\section{ACKNOWLEDGEMENTS}

The researcher expresses his gratitude to the Higher Education, Research and Development Council or Majelis Pendidikan Tinggi Penelitian dan Pengembangan (Diktilitbang) of Muhammadiyah Central Executive for the 3rd batch of Muhammadiyah Research Grants. Including advice from the reviewer team and sharing from the recipients of the $3 \mathrm{rd}$ batch of Muhammadiyah Research Grants from various Muhammadiyah Universities in Indonesia. 


\section{REFERENCES}

Abu-Nimer, M. and Smith, R. K. (2016). Interreligious and intercultural education for dialogue, peace and social cohesion. International Review of Education 62, 393-405. doi: 10.1007/s11159-016-9583-4.

Akerlof, G. A. and Kranton, R. E. (2010). Identity Economics: How Our Identities Shape Our Work, Wages, and Well-Being (New Jersey: Princeton University Press), 1-192.

Burch-Brown, J. and Baker, W. (2016). Religion and reducing prejudice. Group Processes \& Intergroup Relations 19, 784-807. doi: 10.1177/1368430216629566.

Burhani, A. N. (2018). Pluralism, Liberalism, and Islamism: Religious Outlook of Muhammadiyah. Studia Islamika 25, 433-470. doi: 10.15408/sdi.v25i3.7765.

Christie, D. J. and Dawes, A. (2001). Tolerance and solidarity. Peace and Conflict: Journal of Peace Psychology 7, 131-142. doi: 10.1207/s15327949pac0702_04.

Cottam, M. L., Mastors, E., Preston, T., and Dietz, B. (2010). Introduction To Political Psychology : 2nd Edition (New York: Psychology Press), 1-416.

Dixon, J., Cakal, H., Khan, W., Osmany, M., Majumdar, S., and Hassan, M. (2017). Contact, Political Solidarity and Collective Action: An Indian Case Study of Relations between Historically Disadvantaged Communities. Journal of Community \& Applied Social Psychology 27, 83-95. doi: 10.1002/casp.2296.

Harisman (2018). Metode Pengajaran AIK bagi Mahasiswa Non-Muslim (Studi Kasus Fakultas Farmasi UMP). In Seminar Nasional Al-Islam dan Kemuhammadiyahan 2018, Universitas Muhammadiyah Surakarta, ed. and others (Publikasi Ilmiah), 87-98.

Haslam, A. (2004). Psychology In Organizations : The Social Identity Approach (London: Sage Publications), 1-336.

Hogg, M. A., van Knippenberg, D., and Rast, D. E. (2012). Intergroup Leadership in Organizations: Leading Across Group and Organizational Boundaries. Academy of Management Review 37, 232-255. doi: 10.5465/amr.2010.0221.

Hook, J. N., Farrell, J. E., Johnson, K. A., Tongeren, D. R. V., Davis, D. E., and Aten, J. D. (2017). Intellectual humility and religious tolerance. The Journal of Positive Psychology 12, 29-35. doi: 10.1080/17439760.2016.1167937.

Isnaini, S. U. (2014). Persepsi Mahasiswa Non Muslim Terhadap Pembelajaran Al-Islam Dan Kemuhammadiyahan Di Universitas Muhammadiyah Malang. http://eprints.umm.ac.id/26458/2/jiptummpp-gdl-shoviumuli-382331-cover\%2Cl-l.pdf.

Kurniawan, K. N. (2018). Religious Tolerance in the Hidden Curriculum: A Case Study on. Indonesian Public School. Masyarakat : Jurnal Psikologi 23, 1-30. doi: https://doi/org/10.7454/mjs.v23i1.7841.

Kusuma, W. (2016). Indahnya Toleransi Di Kampus-Kampus Yogyakarta. https://regional.kompas.com/read/2016/12/23/05535791/indahnya.toleransi. di.kampus-kampus.yogyakarta?page=3pada12Maret. (Accessed on 2020-0720).

Matulessy, A. (2018). Psikologi Politik : Dari Ideologi Kebangsaan Hingga Gerakan Mahasiswa (Malang: Intrans Publishing).

Muhammadiyah, S. (2017). Manhaj Moderat berkemajuan. https: //www.suaramuhammadiyah.id/2017/07/12/manhaj-moderat-berkemajuan/. (Accessed on 2020-07-13).
Muhammadiyah, S. (2018). Daftar Perguruan Tinggi Muhammadiyah dan 'Aisyiyah 2018. http://www.suaramuhammadiyah.id/2018/11/23/daftar-perguruantinggi-muhammadiyah-dan-aisyiyah-2018/pada25Maret. (Accessed on 202007-16).

Mukti, A. and Haq, F. R. U. (2009). Kristen Muhammadiyah : Konvergensi Muslim dalam Pendidikan (Jakarta: Al-Wasat Publishing House), 1-265.

Neuberg, S. L., Warner, C. M., Mistler, S. A., Berlin, A., Hill, E. D., Johnson, J. D., et al. (2014). Religion and Intergroup Conflict: Findings From the Global Group Relations Project. Psychological Science 25, 198-206. doi: 10.1177/ 0956797613504303

Pohl, F. (2009). Interreligious Harmony and Peacebuilding in Indonesian Islamic Education (New York: Springer). doi: https://doi.org/10.1007/978-1-44190143-9 8.

Pusat, M. P. (2009). Pedoman Islami Warga Muhammadiyah (Yogyakarta: Suara Muhammadiyah).

Sammut, G. and Gillespie, A. (2011). Editorial: Cultural Encounters and Social Solidarity. Papers on Social Representations 20, 1-7.

Setiawan, T., Scheepers, P., and Sterkens, C. (2020). Applicability of the social identity model of collective action in predicting support for interreligious violence in Indonesia. Asian Journal of Social Psychology 23, 278-292. doi: 10.1111/ajsp.12397.

Smith, J. A., Flowers, P., and Larkin, M. (2013). Interpretative Phenomenological Analysis : Theory, Method, and Research (Singapore: Sage Publication), 1-232.

Smith, J. A. and Osborn, M. (2006). Qualitative Psychology A Practical Guide to Research Methods (Sage Publications).

Tajfel, H. (1982). Social Psychology of Intergroup Relations. Annual Review of Psychology 33, 1-39. doi: 10.1146/annurev.ps.33.020182.000245.

Untung, S. H. and Sutrisno, E. A. (2015). Sikap Islam terhadap Minoritas NonMuslim. Kalimah: Jurnal Studi Agama dan Pemikiran Islam 12, 27-48. doi: http://dx.doi.org/10.21111/klm.v12i1.217.

Wibisono, S., Louis, W., and Jetten, J. (2019). The Role of Religious Fundamentalism in the Intersection of National and Religious Identities. Journal of Pacific Rim Psychology 13, 12-12. doi: 10.1017/prp.2018.25.

Zarkasyi, H. F. (2012). Misykat: Refleksi Tentang Islam, Westernisasi, dan Liberalisasi (Jakarta: Institute for the Study of Islamic Thought and Civilizations \& Majelis Intelektual dan Ulama Muda Indonesia).

Conflict of Interest Statement: The authors declare that the research was conducted in the absence of any commercial or financial relationships that could be construed as a potential conflict of interest.

Copyright (C) 2021 Hamzah, Akbar and Grafiyana. This is an open-access article distributed under the terms of the Creative Commons Attribution License (CC BY). The use, distribution or reproduction in other forums is permitted, provided the original author(s) and the copyright owner(s) are credited and that the original publication in this journal is cited, in accordance with accepted academic practice. No use, distribution or reproduction is permitted which does not comply with these terms. 


\section{LIST OF TABLES}

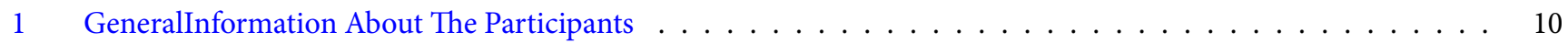

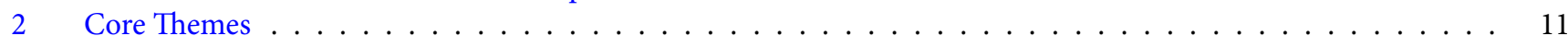


TABLE 1 | Generallnformation About The Participants

\begin{tabular}{lllllll}
\hline Participant & 1 & 2 & 3 & 4 & 5 & 6 \\
Pseudonym & D & F & L & T & W & \\
Semester & 5 & 3 & 5 & 5 & 5 & 3 \\
Religion & Buddha & Catholic & Christian & Catholic & Hindu & Christian \\
Sex & Female & Male & Female & Female & Female & Male \\
\hline
\end{tabular}


TABLE 2 | Core Themes

\begin{tabular}{|c|c|c|c|c|c|}
\hline D & $\mathrm{F}$ & $\mathrm{L}$ & $\mathrm{T}$ & W & $\mathrm{B}$ \\
\hline \multicolumn{6}{|c|}{ Familiy Influence } \\
\hline $\begin{array}{l}\text { Familyable } \\
\text { parents }\end{array}$ & $\begin{array}{l}\text { Tolerant } \\
\text { parents }\end{array}$ & Dependent to parents & $\begin{array}{l}\text { Families experiences in } \\
\text { college education }\end{array}$ & Security among families & $\begin{array}{l}\text { Parents education about } \\
\text { responsibility }\end{array}$ \\
\hline \multicolumn{6}{|c|}{ Personal characteristics } \\
\hline $\begin{array}{l}\text { Learn new } \\
\text { things }\end{array}$ & $\begin{array}{l}\text { Loyal and } \\
\text { responsible }\end{array}$ & Open & Respecting & Love a challenge & Autonomous \\
\hline \multicolumn{6}{|c|}{ Judgment to the committed religion } \\
\hline $\begin{array}{l}\text { Worship is a } \\
\text { choice }\end{array}$ & $\begin{array}{l}\text { Religion is a } \\
\text { love }\end{array}$ & humble religion & Respecting others & Enjoyful prayers & Exreligion \\
\hline \multicolumn{6}{|c|}{ Experience as a Muhammadiyah Student } \\
\hline $\begin{array}{l}\text { Tolerant } \\
\text { university }\end{array}$ & $\begin{array}{l}\text { Respecting } \\
\text { diversity }\end{array}$ & $\begin{array}{l}\text { Environment which accepts } \\
\text { their presences }\end{array}$ & $\begin{array}{l}\text { Satisfaction of university } \\
\text { services }\end{array}$ & $\begin{array}{l}\text { Leadership and environment } \\
\text { which are respecting }\end{array}$ & Place to have networks \\
\hline \multicolumn{6}{|c|}{ Judgment to Islam and Muhammadiyah } \\
\hline $\begin{array}{l}\text { Mostly } \\
\text { tolerant }\end{array}$ & $\begin{array}{l}\text { Confusing } \\
\text { religion }\end{array}$ & Good religion & Polite religion & Muslim perseverance & Muslim is sacred \\
\hline
\end{tabular}

